\title{
Upstream Stimulatory Factor 2
}

National Cancer Institute

\section{Source}

National Cancer Institute. Upstream Stimulatory Factor 2. NCI Thesaurus. Code C38370.

Upstream stimulatory factor 2 (346 aa, $\sim 37 \mathrm{kDa}$ ) is encoded by the human USF2 gene.

This protein is involved in gene expression. 